\title{
Cost evaluation of Typhoid fever in Indonesia
}

\author{
Narain H. Punjabi
}

\begin{abstract}
Abstrak
Demam tifoid merupakan penyakit endemik di indonesia. Hasil dari studi epidemiologi dan survei rumahtangga memperlihatkan bahwa insidens penyakit ini di Indonesia berkisar antara 358-810/100.000 populasitahun. Sebagian besar (90\%) pasien merupakan pasien rawat jalan dan mendapat pengobatan antibiotika selama 2 minggu. Kasus yang lebih parah membutuhkan rawat inap untuk kita-kira 5 hari sampai 2 minggu. Pada tiga sampai lima persen kasus rawat inap timbul komplikasi. Mortalitas dari kasus ini kira-kira antara 0,6-2\%. Karena populasi total Indonesia adalah 200 juta, diperkirakan terdapat 1,08 juta kasus demam tifoid baru di Indonesia setiap tahun. Biaya pengobatan pasien rawat jalan untuk kasus demam tifoid ringan diperkirakan sekitar US \$50-150, sementara kasus rawat inap tanpa komplikasi sekitar \$100-500 dan kasus komplikasi akan menelan biaya \$250 atau lebih. Semua gambaran ini tergantung pada pilihan antibiotika yang digunakan (kloramfenikol vs kuinolon atau sefalosporin generasi ketiga), kemampuan pasien, pilihan rumah sakit (pemerintah atau swasta), respon pasien terhadap pengobatan, preferensi dokter untuk memulangkan pasien (cepat atau beberapa hari setelah demam turun). Sebagian besar pasien demam tifoid tidak mampu datang ke tempat kerja atau sekolah untuk ratarata 20-30 hari sebelum mereka dapat menjalankan aktivitas normal. Selain itu, selain pasien, biasanya aktivitas dari 1 atau 2 orang anggota keluarga terganggu untuk memenuhi kebutuhan pasien (baik untuk pasien rawat inap ataupun rawat jalan). Semua ini, dengan diet khusus, transportasi dan lain-lain menambah hilangnya pendapatan keluarga. Diperkirakan biaya demam tifoid sekitar US $\$ 60$ juta untuk mengobati, pendapatan berkurang sebesar $\$ 60$ juta dan mortalitas penyakit sebesar 6.500-20.000 pertahun di Indonesia. Vaksin yang sederhana, efektif, murah dengan efek samping yang rendah, serta program pendidikan masyarakat dapat menurunkan beban penyakit ini.
\end{abstract}

\begin{abstract}
Typhoid fever is endemic in Indonesia. Epidemiologic studies and household surveys show that the incidence of this disease in Indonesia is between 358-810/100,000 population/year. The majority of these patients (estimated 90\%) are managed as outpatients and receive antibiotic treatment for approximately 2 weeks, depending upon type of antibiotic used. More severe cases require hospitalization for about 5 days - 2 weeks. Between 3-5\% of cases develop complication(s). The mortality of this disease is between 0.6-2\%. Since the total population of Indonesia is 200 million, it is estimated there are 1.08 million new cases of typhoid fever in Indonesia every year. Outpatient treatment cost for a mild typhoid fever case is estimated at \$50-150.-. Hospitalization cost for uncomplicated case is about $\$ 100-500$.-; a complicated case would cost $\$ 250$.- or more. These figures depend upon the choice of antibiotic used (chloramphenicol vs. quinolone or 3 rd generation cephalosporin), patient's ability to pay, choice of hospital (government vs. private), patient's response to the treatment, and doctor's preference for time of discharge (immediately vs. several days after defervescence). Most typhoid fever patients are unable to attend work or school for an average of 20-30 days. In addition, usually 1 or 2 other family members activities are disrupted to care for the patient (for both in and outpatient). These along with the special diet, transport etc. add to the family's burden and loss of income. It is estimated that treatment of typhoid fever costs almost US $\$ 60$ million and there is also about $\$ 60$ million loss of income. Mortality of this disease is estimated at 6,500-20,000 per year in Indonesia. A vaccine that is simple to administer, has good efficacy, high compliance, and is inexpensive with low side effects with effective public health education, could reduce this disease burden.
\end{abstract}

\section{INTRODUCTION}

Typhoid fever is endemic in Indonesia. Medical publications mentioned the existence of this disease in Indonesial since the last century. Surveillance and data submitted to the Center for Disease Control in Indonesia document that it exists in every province and there is no sign of reduction in its incidence 2 . Results from blood culture-confirmed and carefully conducted epidemiologic studies show that the inci-

US NAMRU-2, Jakarta, Indonesia. dence of this disease at least similar or higher than the average figures for its incidence in other developing countries ${ }^{3-5}$. In addition some hospital observations indicate increasingly severe manifestations of this disease in Indonesia and several other developing countries $^{6}$. It is commonly considered in the differential diagnosis for patients with fever longer than 4 days; in some areas it accounts for $25 \%$ of hospitalized febrile patients 7 . Difficulties in establishing a rapid and accurate diagnosis also add to the magnitude of problem caused by this disease in Indonesia ${ }^{8}$.

In order to estimate the financial cost and burden of this disease, both for treatment and loss of income in- 
curred by the patient and the family, a calculation was made based upon the incidence, cost of treatment \& hospitalization and Gross National \& Domestic Product (GNP \& GDP) per capita income for Indonesia.

\section{MATERIAL AND METHOD}

Data and figures were collected from various medical facilities including hospitals, private clinics, pharmacies and practicing physicians in and around Jakarta. Various articles and papers regarding typhoid fever, including results of household surveys and data submitted to the Communicable Disease Control (CDC) Directorate Of Ministry of Health R.I., health care and its cost in Indonesia, were utilized as reference. Calculations regarding the cost of treatment and hospitalization were made in Indonesian rupiahs and then converted into US dollars prior to the onset of 1997 Asian monetary crisis. The current cost would be lower for Indonesia but only temporarily before the price stabilization takes place.

Incidence data was taken from community studies conducted by Simanjuntak and colleagues for both rural and urban areas 3,4 . Although they were conducted in the mid 1980s, hospital observations and surveillance data submitted to Indonesia CDC showed that typhoid fever incidence in Indonesia is at least similar and maybe even higher for certain areas. Edelman and Levine's 1986 estimate for the average incidence for developing countries was used to calculate the approximate total number of cases ${ }^{6}$. Official statements in 1997 give the total population of Indonesia as over 200 million.

\section{RESULTS}

\section{Incidence}

Epidemiology studies conducted in 1984 in Paseh, West Jawa and Plaju, South Sumatera show that the incidence of typhoid fever was $358 / 100,000$ population/year for the rural area and 810/100,000 population/year for the urban area. The average, 540/ 100,000 population/year, as mentioned by Edelman and Levine in 1986, was used for calculation of total cases. With total population of 200 million, it is estimated there are 1,080,000 new cases of typhoid fever per year in Indonesia. Results of these studies were based upon positive blood cultures from febrile patients living in the areas. Since the best result of blood culture for Salmonella typhi yield only $80 \%$, the actual number of estimated cases is probably higher. The total number of cases submitted to the Indonesian CDC does not reach this estimate, although there is a trend showing increase over the last several years. The lower number of cases submitted to CDC could be due to the fact that most physicians in private practice do not submit reports of typhoid fever cases even if they are blood culture positive. These studies also showed that almost $90 \%$ cases are children and young adults below the age of 19 years. Hospital observations differ somewhat, with higher number of adults between age 20-30 years being admitted. This could be attributed to the larger number of differential diagnoses for febrile illness observed in children, and also to the ease managing children's illness at home compared to adults.

\section{Case Management}

Most (90\%) of typhoid fever cases are managed as outpatients and receive antibiotic therapy for several days to 2 weeks 9 . Typhoid fever patients generally make at least one or more trip to the health care provider, which could be practicing physician, hospital polyclinic, Puskesmas (community health center), or nurse practitioner. They generally order some laboratory test(s); most often Widal test due to the need for a rapid result, to confirm the illness. Patient also receive various other medications, including anti-pyretics and vitamins during the course of the illness. In Indonesia, when the working diagnosis is typhoid fever, the patient is usually advised to eat special diet, either puree or soft diet without fibre.

Chloramphenicol is widely prescribed, and fortunately more than $95 \%$ of isolated strains are still sensitive to it 9 . Other commonly prescribed drugs are ampicillin/amoxicillin and combination of trimethoprim \& sulfamethoxazole, although they are slightly less potent against the isolated Salmonella typhi strains. Newer antibiotics such as quinolones and third generation cephalosporins are gaining popularity among practicing physicians, however contraindication in children and affordability limit their use for pediatric typhoid fever patients.

About $10 \%$ of cases are hospitalized for various reasons, with patient's condition as the most often cause for it. Besides the similar management, including laboratory tests and antibiotic prescription, the patient will have additional laboratory examinations, including blood culture, complete blood counts, liver function tests etc. The patient will also receive stricter diet or the family will provide special food from outside that is allowed, since many of them ex- 
perience nausea and dislike the hospital diet. Hospitalization for typhoid fever generally lasts for a period of 5 days to 2 weeks.

The rate of complications in typhoid fever varies from 3 to $5 \%$. Many publications have mentioned various complications, ranging from mild intestinal bleeding, (impending) intestinal perforation, to altered mental status and shock 10 . These conditions prolong the total bedrest and hospitalization. They also require consultation with other specialists, particularly the surgeons. Stronger antibiotics (preferably via parenteral route) and other drugs or treatment modalities, including transfusions etc. are frequently prescribed for these patients.

\section{Case Fatality}

Present population of Indonesia is 200 million and crude death rate is about 7.6/1000 population/year11. In the Indonesian medical literature it is mentioned that the case fatality rate (CFR) for typhoid fever although has declined in the last several years, approximately about $0.6-2 \%$, which means $6,480-21,600$ deaths/year. Data from 1986 household survey mentioned that $3.3 \%$ of all deaths could be attributed to typhoid fever. If the result of this verbal autopsy was correct and the rate remain the same for current situation, it would result in total of 50,160 deaths/yr. Another estimate, by Kosen in his paper: "Estimation of National Burden of Disease, an Indonesian experience", presented at SEAMIC Technical Meeting on Health Statisics in Yogyakarta in 1996, mentioned a total of 9,420 deaths attributable to typhoid fever ${ }^{12}$.

\section{Cost of Treatment and Hospitalization}

Many factors affect the cost of treatment for typhoid fever in Indonesia: what the patient can afford, type of health care provider (government vs. private), choice of antibiotic (chloramphenicol vs. quinolone or 3rd generation cephalosporins), response to the treatment, and doctor's preference for time of discharge (immediately vs. several days after defervescence), etc. For patient who has few resources, the health care provider may treat the patient for typhoid fever based upon clinical judgement, without any laboratory confirmation. These patients generally receive chloramphenicol $50-100 \mathrm{mg} / \mathrm{kg}$.body weight/day, in 4 divided doses, usually $500 \mathrm{mg} 4 \mathrm{x}$ /day per oral for an adult. Although it often strikes patients from the lower socioeconomic group, due to their limitation for better hygiene practice, typhoid fever is also observed among well to do patients in Indonesia. More affluent patients will receive a quinolone or brand name drugs that are costlier; they also have more frequent visits to their private physicians, more laboratory work and are more likely to be hospitalized. Considering drug costs, fees to the health care provider, laboratory tests, special diet and costs of relapse, it is estimated that the average cost of outpatient treatment for typhoid fever is US\$ 50-150.-/patient. Total cost for this group would be $90 \% \mathrm{x}$ $1,080,000 \times \$ 50 .-=\$ 48,600,000$.-

Similar calculations can be made for uncomplicated hospitalized typhoid fever case. There is wide variation between the cost of a government hospital in a small town and a "5 star" hospital in big metropolitan area (which are as expensive as hospitals in developed countries). The average cost of hospitalization for typhoid fever is US $\$ 100-500$.-/patient in a government hospital.

Three to $5 \%$ of typhoid fever patients develop complications, which require more intensive monitoring, laboratory tests, parenteral therapy, and prolong the stay in the hospital. These things significantly increase the cost of hospitalization to US\$ 250 .- or more.

Estimated expenditure for hospitalization is : $97 \% \mathrm{x}$ $10 \% \times 1,080,000 \times \$ 100 .+3 \% \times 10 \% \times 1,080,000 \times$ $\$ 250 .-=\$ 10,476,000 .-+\$ 810,000=\$ 11,286,000$.The total cost of treatment for in and outpatients for typhoid fever is estimated as: $\$ 48,600,000 .-+$ $11,286,000 .-=\$ 59,886,000$.- .

\section{Loss of Income}

Typhoid fever is a systemic illness and cause a prolonged febrile episode. The patient generally feels quite weak during the illness and after defervescence, manifested by symptoms of malaise and requirement of rest during convalescence. This results in patient's dependence on assistance from other family members during their sickness, even if they are hospitalized, and in the recovery period. The average amount of time lost from work for typhoid fever patients is 20 30 days. Even if they are not working, their illness generally causes disruption of 1-2 other family member's work schedule during the sickness and convalescence periods. On average there is about 20 work days loss of income for family members. If Indonesian Gross National Product (GNP) per capita income for 1997 is estimated at US\$ 1000.-11, the loss of income would be : $20 / 365 \times 1,080,000 \times \$ 1000 .-=\$$ $59,178,082$.- 


\section{DISCUSSION}

This conservative mathematical exercise shows that the cost of typhoid fever for Indonesia is almost US\$ 120 million and at least 6,500 deaths annually, which is a significant amount for a developing country. This amount is still far from the amount estimated by Kosen in his paper for DALY (Disability Adjusted Life Years) measurement, which is 345,000 life-years and 9,420 deaths for typhoid fever. If this figure is multiplied by per capita income, that could result into \$ 345 million.

Although the amount mentioned in this calculation as $\$ 120$ million is only an estimate, its importance is to show that a significant amount of money and lives could be saved if preventive measures are taken. A vaccine that is simple to administer, has high efficacy, is inexpensive, has few side effects and promotes compliance, along with effective public health education, could reduce the disease burden and prevent mortality in Indonesia and other developing countries.

\section{REFERENCE}

1. Kouwenaar W, Van Steenis PB, Winckel CWF (eds). Leerboek der Tropische Geneeskunde. NV Scheltema \& Holkema, Amsterdam \& NV Soeroengan, Djakarta 1956; 255-75.

2. Ministry of Health, Republic of Indonesia, Directorate Communicable Disease Control and Environmental Health, Sub Directorate of Surveillance, Surveillance Data Jakarta, 1993-5.

3. Simanjuntak CH, Hoffman SL, Punjabi NH, Edman DC, Hasibuan MA, Sumarno W, Koiman I. Epidemiologi Demam Tifoid di suatu daerah pedesaan di Paseh, Jawa Barat. Cermin
Dunia Kedokteran 1987; 45: 16-8.

4. Simanjuntak $\mathrm{CH}$, Paleologo FP, Punjabi NH, Darmowigoto R, Soeprawoto, Totosudirjo H, Haryanto PP, Supriyanto E, Witham ND, Hoffman SL. Oral immunization against typhoid fever in Indonesia with Ty21a vaccine. Lancet 1991; 338: $1055-9$.

5. Edelman R, Levine MM. Summary of Intemational workshop on typhoid fever. Rev Infect Dis 19.86; 8: 329-49.

6. Ivanoff B. Typhoid fever: Global situation and WHO recommendation. Southeast Asia J Trop Med Publ Health 1995; 26(S2): $1-6$.

7. Anderson KE, Joseph SW, Nasution R, Sunoto, Butler T, Van Peenen PFD, Irving GS, Saroso JS, Watten RH. Febrile illness resulting hospital admission: A Bacteriological and Serological study in Jakarta, Indonesia. Am J Trop Med Hyg 1976; 25(1): 116-20.

8. Punjabi NH. Laboratory diagnosis of typhoid fever: A challenge for the 1990s. Presented at XIII Int. Congress for Tropical Medicine and Malaria, Jomtien Thailand, Nov. 29 Dec.4, 1992.

9. Setyoboedi. Penderita demam tifoid dapat dirawat di rumah (Typhoid fever patient could be treated at home). Medika 1997; 12: 928-9.

10. Hoffman SL, Punjabi NH, Kumala S, Mochtar MA, Pulungsih SP, Rivai AR, Rockhill RC, Woodward TE, Loedin AA. Reduction in Chloramphenicol-treated severe typhoid fever by high dose dexamethasone. New Englamd J Med 1984; 310: 82-8.

11. Kosen S. Health care in Indonesia in the $21^{\text {th }}$ century, presented at the International Conference on Emerging Health problems in the 21 th century in the Asia-Pacific region,Taipei ROC, October 19-20, 1997.

12. Kosen S. Estimation of National Burden of Disease, an Indonesian experience", presented at SEAMIC Technical Meeting on Health Statisics, Yogyakarta Indonesia, 5-9 August 1996. 